\title{
City Branding and Public Space. An empirical analysis of Dolce \& Gabbana's Alta Moda event in Naples
}

\author{
Francesco Rossini \\ The Chinese University of Hong Kong, Hong Kong \\ School of Architecture \\ rossini@cuhk.edu.hk \\ Esterina Nervino \\ Universita' degli Studi di Modena e Reggio Emilia, Italy \\ Department of Studies on Language and Culture \\ esterina.nervino@gmail.com
}

\begin{abstract}
This article focuses on the celebration of the thirtieth anniversary of D\&G held in Naples in June 2016. For this event iconic places of the city were used as the backdrop of the Alta Moda Fall/Winter 2016 collection. For a few days, access to different areas of 'Centro Storico' (the Neapolitan's downtown) were closed to the general public generating controversial opinions on the phenomenon of privatization of the public space.

The study presents an empirical analysis of the video produced for the event and it focuses on the elements that characterize Naples as a cultural artefact capturing the authenticity of Southern Italy and simultaneously meeting the brand values of D\&G. The findings revealed how the urban space becomes a tool to emphasize the core values of the fashion brand and how this process enhances the image of the city as a historical and cultural centre, essence of Mediterranean and Italian culture.
\end{abstract}

Keywords: city branding, public space, Naples, Dolce \& Gabbana

To cite this article:

Rossini, F., Nervino, E. (2019). City Branding and Public Space. An empirical analysis of Dolce \& Gabbana's alta moda event in Naples, The Journal of Public Space, 4(4), 6I-82, DOI I0.3289I/jps.v4i4.1234

This article has been double blind peer reviewed and accepted for publication in The Journal of Public Space. (2) This work is licensed under a Creative Commons Attribution - Non Commercial 4.0 International License https://creativecommons.org/licenses/by-nc/4.0/ 


\section{Introduction}

[...] We love the streets. It is still like the 1950s here, in a way. This is a place that hasn't lost its roots and we appreciate that. We enjoy big cities and technology and embracing the future but to understand the life of the Italian people you need to see their roots. [...] We spent a lot of hours exploring the streets. And very quickly we fell in love with this place. We love the contrasts, between fashion and life, between modern and classic. And the people... they are all very sincere and dramatic - very movie actor. (Dolce \& Gabbana on Facebook)

In the past few years, renowned fashion firms have used urban spaces to link the image of a city to their brands and products and vice versa. Fendi used the Trevi Fountain in Rome as a catwalk and Chanel introduced Cuba to the world staging a fashion runaway in the city centre of Havana. However, the fashion brand to pioneer this trend was Dolce \& Gabbana (hereafter D\&G), with its Alta Moda fashion show in the city centre of Naples in June 2016. After that, they made it their trademark signature and D\&G continued to occupy urban spaces around Italy. In September, during the 2016 Milan Fashion Week, they hosted a banquet in Via Montenapoleone for 400 guests and celebrated the opening of the new D\&Gs' flagship store in Milan. Likewise, the same year they used the city of Palermo and Naples to showcase their collections. These events re-open the debate on the use of public space for private branding purposes. This study focuses on the celebration of the thirtieth anniversary of D\&G held in Naples last June 2016. For a few days iconic places such as Palazzo Donn'Anna, San Gregorio Armeno and Borgo Marinari, were used as the backdrop of the Alta Moda Fall/Winter 2016 collection (Figure I).

For the event, access to different areas of 'Centro Storico' (the Neapolitan's downtown) were closed to the general public generating controversial opinions on the phenomenon of privatization of the public space.

Given the international exposure produced by D\&G including their shows, presentations, and advertising campaigns, the brand was exempted from paying occupancy of public land to the municipality of Napoli. The fashion brand however contributed with consistent donations, which were used by the municipality to restore parts of the city such as buildings and monuments, used as a stage for the fashion shows. As such, the central question of this article is to explore how the use of temporary events can have a positive outcome for the city and the local community. Although the use of city branding to attract private funding and investments has been well documented (Dinnie, 20I I; Cleave et al., 2016; Dastgerdi \& De Luca, 2019), few studies have examined how urban spaces are used to emphasize a process that has an impact on both the image of the city and brand identity. 


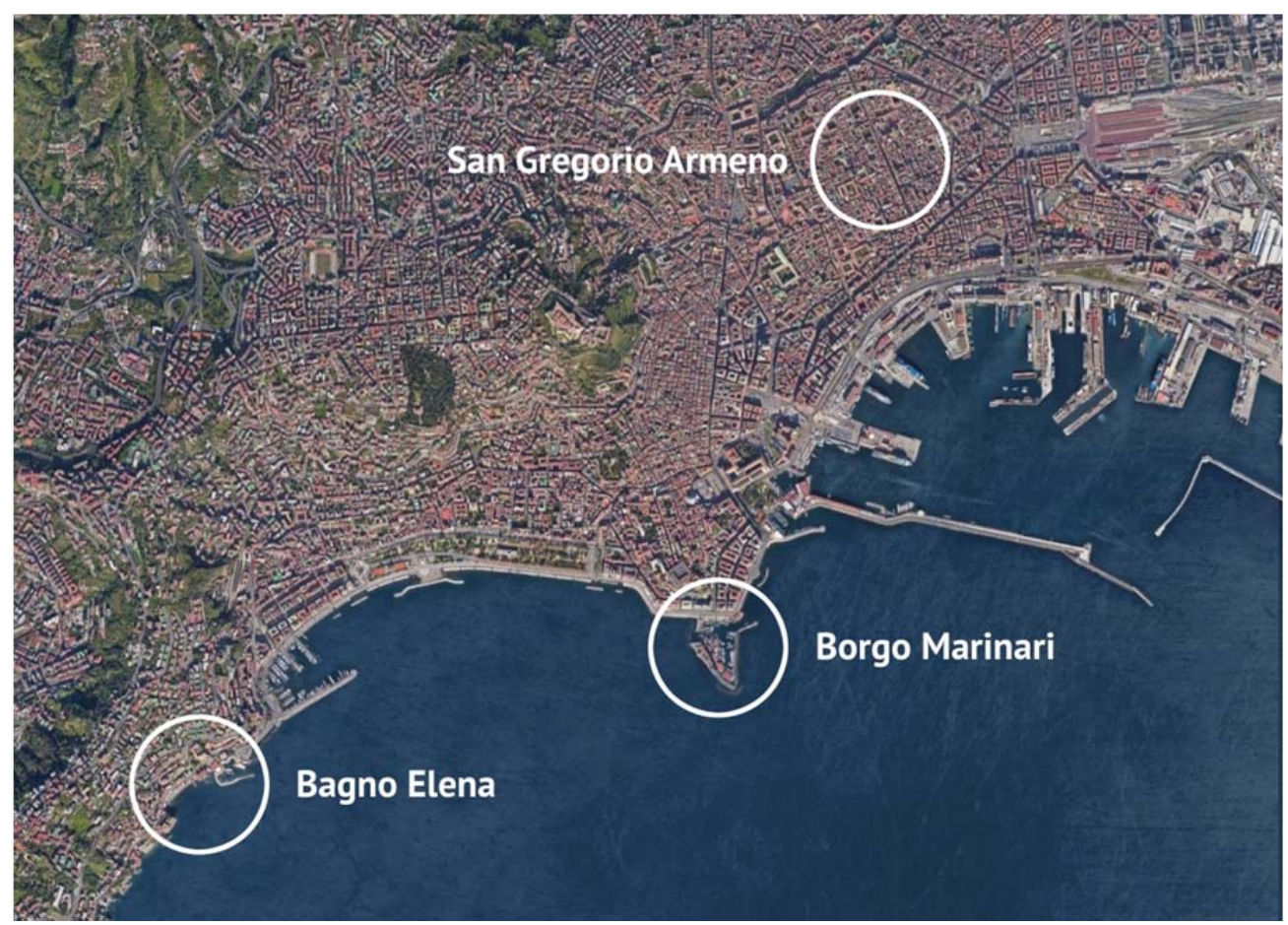

Figure I. The locations chosen for the thirtieth anniversary of Dolce \& Gabbana.

In this article, the thirtieth anniversary of D\&G is examined through an empirical analysis of video and media created for the event (Hall, 2006). The study focused on elements that characterize Naples as a cultural artefact that captures the authenticity of Southern Italy and meets the brand values of D\&G. The analysis revealed how the urban space is used to emphasize the core values of the fashion brand and how it enhances the image of the city as a historical and cultural centre as the essence of Mediterranean and Italian culture.

Furthermore, the results suggest that this type of mutual branding between public and private, can be a valuable tool not only for promoting the city but also in the maintenance of historic and cultural heritage. These temporary partnerships can have a positive impact on the regeneration of urban structures as well as promoting cities as cultural and fashion symbols.

The manuscript is organized as follows: a review of the concept of space in its public and private domain; the city from physical entity to narrative text; the analysis of the video; a conclusion explaining how private interests can benefit the community.

\section{Cities, private and public realm}

According to Aldo Rossi (1982), the city, or more specifically its architecture, represents represent the stage of all human activities; the almost permanent physical condition of spaces is animated with the mutating actions of the people who inhabit them. Hajer \& Reijndorp (200I) argued that spaces are never fixed, the public domain comes into these spaces being in flux, often extremely temporarily. Richard Sennett (1978: 39) defines a city as "....a human settlement in which strangers are most likely to 
meet". In paintings of the French Impressionists, the flow of people is merged with the architecture of the city and the street becomes the place that facilitates the civic exchange and social interaction.

Amanda Burden (2014), urban planner and former director of the New York City Department of City Planning, stresses that cities are about people: where people go and where they meet are central to the functioning of the city. In her view, the public spaces between buildings are more important than the buildings themselves; some of the most transformative urban initiatives are currently occurring in these public spaces. Similarly, Crowhurst-Lennard and Lennard (2015) argued that urban public space is the single most important element of a city's liveability.

Recently, many studies have provided evidence of the significant role played by public spaces in increasing a city's attractiveness by encouraging local business investment and improving local living conditions (PPS, 2000; Leinberger \& Berens, 1997). Over time the use of public spaces has evolved gaining more complex functions. Currently new types of spaces are flourishing, and old typologies are being retrofitted to meet the needs of the contemporary society (Metha, 20I5).

However, over the course of the twentieth century, the public sphere appears to have become increasingly fragile. The urban transformation initiatives implemented in the 1990s designed to expand consumption and privatization, led to public space crises. According to Cuthbert and McKinnel (1997), these trends caused a shift in terms of responsibility from public to the private sector. During an interview with Jennifer Sigler the Dutch architect Rem Koolhaas (2000), argued that the nature of a city has changed radically from being public to private. Provocatively, he describes how each urban activity is always more based on commercial transactions. According to Banerjee (200I), places such as bookstores, cafes, shopping centres, hotel lobbies and rooftop terraces are becoming the new urban spaces of contemporary society. Oldenburg $(2009,2)$ defines these collective spaces as a "third place" in "which people relax in good company on a regular basis". However, the need for new types of social spaces may lead to the supremacy of private over public interests with the consequence of "... abandoning the principle of free, open and democratic access in favour of a policy of actively restraining and excluding those deemed not to belong" (Graham 200 I: 365).

One of the distinguishing features of public space is its accessibility of use. The distinction between public and private is not always a rigid dichotomy, there are a number of intermediate transitions where differences may disappear (Rossini, 20I4). Similarly, Carmona (2015: 400) argues that often the spaces of a city “....are owned and managed through multiple complex arrangements, many of which are not clearly public or private".

In many contemporary urban developments, public spaces are often used for private activities, and private spaces allow for collective use generating a range of intermediate hybrid conditions (Rossini et al. 2018). According to Manuel de Solá-Morales (1992) public space should influence the private sphere giving a public character to buildings and places that, without it, would be only private. In other words, urbanizing the private: that is, making it part of the public realm. However, if the urban richness of the contemporary city resides in the collective spaces that are not strictly public or private, but both simultaneously (de Solá-Morales, 1992) how can the collaboration of public and private sectors contribute to the delivery and management of successful urban 
spaces? How can a regulated partnership between public and private benefit the public life of our cities?

Nowadays, the private sector's ability in the management of public space must be considered, however, the challenge of this phenomenon it is to find the right balance between public and private interests as well as safeguarding the public realm. The Rockefeller Center in New York, for example, is one of the most visited destinations in the city but is managed and owned by the private sector. Initially, this space, which hosts one of the most famous ice skating rink of the world, was reserved only to the users of the complex, however, only after the opening to the general public, it was possible to appreciate the full potential of this collective space that, through the sensible composition of its architectural forms, creates an intense place of social activities (de Solá Morales, 1992).

\title{
Identity and beauty, the power of the city
}

\author{
Why did we give up beauty? \\ Why did we eliminate it from our cities? \\ ... yet we have always known it. \\ The loss of beauty coincides, \\ has always coincided, with the death of the city.
}

(Cervellati, 2000: 35)

Parthenope was the name of the siren who, unable to seduce Ulysses with her voice, threw herself into the sea and died. According to Greek mythology, Parthenope's death has generated the city of Neapolis. Defined by Benedetto Croce (1927) as a paradise inhabited by devils, Naples, since its origins, has always been a city of contrasts, where the opposites encounter and create an unstable but perfect balance. Perhaps the beauty of Naples lies in this continuous search of balance; the strength of its identity emerges from its history which have inextricably linked the city to its territory and its traditions. In 'L'arte di curare la città', Pierluigi Cervellati (2000) argues that the beauty of a city can be characterized by many aspects, but in order to define its identity one must acknowledge the history of the territory as part of its culture. In his view, the beauty that characterizes most Italian Cities is in the essence of their urban structure and the capacity of adapting this structure to the needs of contemporary society. The rediscovery of urban centres, after the dark years of the 1970s, has in fact created a new city branding phenomenon. Cities like New York, Barcelona and most recently Milan have invested in promoting themselves with strategic intent to attract investment, people and capitals.

The Milan venue of Fondazione Prada (Figure 2), conceived by architecture firm OMAled by Rem Koolhaas, is characterized by an articulated architectural configuration which combines seven existing buildings with three new structures (Podium, Cinema and Torre). The project has transformed a distillery dating back to the 1910s into a new arts centre, where a building clad in 24-carat gold leaf, has become one of the most symbolic elements of the urban regeneration in this area of the city. 


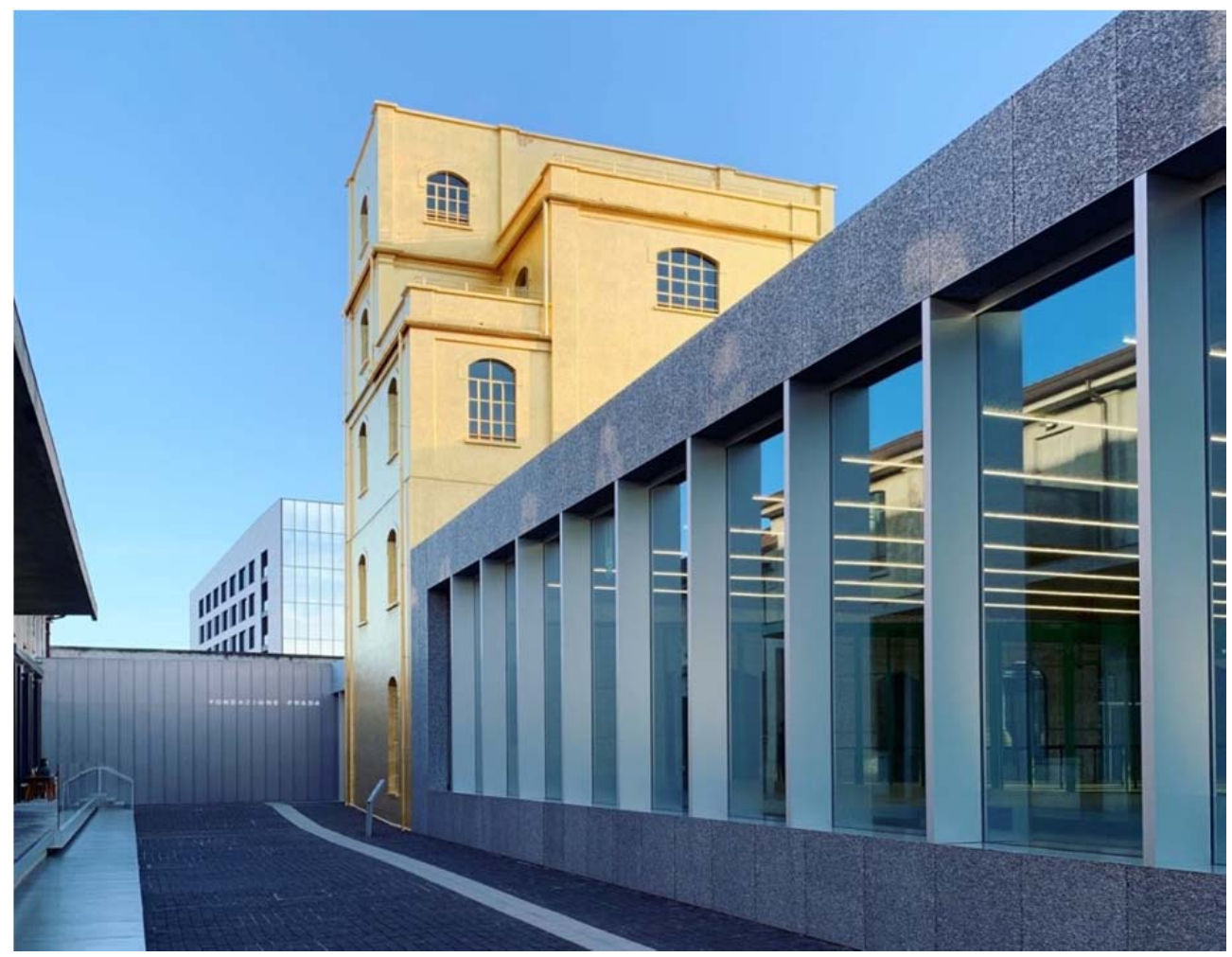

Figure 2. Prada Foundation, Milan (Source: Authors).

This sophisticated cladding gives a new value to a generic building and reminds the imaginary city of Beersheba, made of "...pure gold, with silver locks and diamond gates..." (Calvino, 200I: 252), described in the kaleidoscopic novel Invisible Cities written by Italo Calvino, and where each city has its distinctive quality. The book contains a series of short chapters, each of which is intended to give rise to a reflection which holds good for all cities or for the city in general (Calvino, 1983).

City has been studied as a text on its own having its citizens as first authors acting upon and shaping its space (Karimzadeh et al., 2013). The city is also found to reflect symbols of a community and its cultural artefacts representing the identity of a national culture (Hall, 1995). At the same time, it also becomes part of other texts like the Victorian London described in Charles Dickens' Oliver Twist (1837-39).

Some other scholars have interpreted the city as a system of signs (Barthes, 1987; Hiemslev, 1963; Saussure, 1974) and bridged signifiers and signifieds and applied these concepts to provide socio-cultural changes. Some scholars have focused on the signs reflecting the fast-pace in which developing cities in South East Asia have changed and how the city landscape shows their economic development (Robbie et al., 2003). Jaworski \& Thurlow (2010) also edited a volume to highlight how the linguascape of a city informs its inhabitants about the identities interacting with each other weaving a collective memory. Restaurant billboards, for instance, provide information about the food identity localization and map the population of the city. Likewise, street vendors reflect the social class of the neighbourhood as well as their signage, and also buskers and street artists, graffiti, street fashion, ads, they all reflect the city identity which can 
be unpacked by looking at the material placement of signs advocated as "geosemiotics" (Scollon \& Scollon 2003: 2).

\section{City as a brand}

Brand identity, first theorized by Kapferer (2008) in 1986, is unpacked into a brand concept that incorporates both tangible (e.g. quality of the product) and intangible features (i.e. the idea behind which the brand is associated with), hereafter synthesized into the terms 'values'. Brand identity is built thanks to a name, a logo and particular symbols that are immediately recognizable. These elements work as the communication system for the brand and characterize the brand heritage (Fabris \& Minestroni, 2004). Being D\&G a high-end fashion brand, its value proposition and selling point lies into its brand identity and the maintenance of a dream (Corbellini \& Saviolo, 2007). The keyelements in this dream are: people, legend effect, product, and the country of origin (CoO).

Identity is usually constructed through the presence of the family, the founder (people), and the parent house (place of origin) as elements driving advertising discourse (Fabris \& Minestroni, 2004). In the case of Dolce \& Gabbana, established in 1985, the brand identity is directly linked to the two founders and designers Domenico Dolce and Stefano Gabbana. Domenico Dolce from Sicily is responsible for the leit-motif of Southern Italy in the brand collection. As stated on the website Dolce \& Gabbana's value proposition is based on its "strongly distinctive style and solid DNA, based on artisan sartorial tradition and Mediterranean culture of Italy"'.

The legend effect, interwoven with the product element, 'heritage' (Aaker, 1996) plays a major role, in Italy, where Renaissance is a component of brand history and is reflected in the product design and advertisements to enact intertextual references that contribute to the Renaissance effect (Belfanti, 2015a; 20I5b). 'Made in Italy', for instance, triggers the immediate associations to art, craftsmanship and this savoir faire that is translated in product quality (Kapferer, 2008; Okonkwo, 2007). Likewise, the sense of belonging to a specific country is mediated by its history, language and culture to culminate to a "collective identity" (Donskis, 2009: 74).

The CoO of a brand, in D\&G, is further narrowed down into the South of Italy, which also stands for the major source of inspiration for product design and discursive representations of Italianicity. Dolce \& Gabbana's Italianicity is grounded on the idea that when a product is labeled with the national brand it becomes linked to the country itself (Bucci et al., 20I I). Brands, benefiting from their association with their $\mathrm{CoO}$, remain eternal through time by revamping their heritage and relying on nostalgia (Dion \& Mazzalovo, 2016).

On the association between brands and places of origins, scholars such as Kim et al., 2016 have elaborated on the Italian Fashion Case Study. They focused on Florence specifically as a city that captures its relationship with fashion based on the historical development of the label 'made in' and the mutual branding enacted on each other. Florence has also been investigated as a place of fashion based on the Pitti Uomo event (Aiello et al., 2016) that makes the city the first destination for menswear fashion in

' Dolce \& Gabbana website, http://www.dolcegabbana.com/corporate/en/group/profile.html [Last access $27 / 12 / 2017]$ 
opposition to women's wear in Milan. Florence gained a lot of attention as the city of fashion (Capone \& Lazzaretti, 2016) not only for iconic events, but also because it is home to brands such as Salvatore Ferragamo and Gucci that created museums to celebrate their brand identity and link to the city (Bertoli et al., 2016). Those private initiatives create synergies and interactions among the different stakeholders in the territory (Caroli, 20I4), and empower the city (Jansson \& Power, 2010).

It is nothing new about brands associating themselves to cities, as it is an established practice: Tiffany \& Co. with New York, Prada with Milan, Gucci and Ferragamo with Florence. However, in this sense, Southern Italy, and Naples investigated as a compound of cultural artefacts in relation to brand identity, are a peculiar case as the city is known for its long tradition of sartorial workshops for menswear and cameo jewellery but has never been associated to the fashion system. Cities forge their own brand, defined as the "purposeful symbolic embodiment of all information connected to a city in order to create associations around it" (Lucarelli \& Berg, 20 I I: $2 \mathrm{l}$ ). Studies on the marketing of urban places have populated the literature since a long time and the interest has increased even more because of globalization, competition and hypermobility of capitals. Studies span from the definition of the city as a mere commodity to socio-cultural entities (Kavaratzis, 2004), to the involvement of social innovation policy and architectural theory and practice (Reem et al., 20I2). Most studies examine city branding from an architectural and design point of view (Lau \& Leung, 2005; Muratovski, 2012). Other studies shift attention to the representation of the cities to the outside world (Hospers, 2009).

Additionally, discussing city branding, the attention of scholars has increasingly moved to the effects of events such as the Olympics (Waitt, 1999; Zhang \& Zhao, 2009; Herstein

\& Berger, 20I3), sports competitions (Westerbeek et al., 2002; Smith, 2005), trade fairs (Kowalik, 20I2), Expos (De Carlo et al., 2009) and some city events (Liu \& Chong, 2007; Richards \& Wilson, 2004). In all studies, the target audience of the city representation are tourists. Scholars identify the events as branding tools to create global city images, and more specifically 'public relations' for cities (Xue et al. 20I2). Some other studies focus on media and advertising of cities (Avraham, 2000), others on the storytelling around cities created to project the desired image of the city (Sevcik, $201 \mathrm{I})$. Nickerson and Moisey (1999) define city branding as the relation between people and the city, more relevant to the present study.

The literature shows the research gap in combining diverse disciplines to investigate the identity of urban places in relation to events.

\section{About the event}

Before the event, Domenico Dolce, in an interview, explained that the purpose of the fashion show in Naples was to enrich the brand and tie it to the Italian culture in all its facets: art, architecture, but also 'mozzarella', 'pasta', and all those elements that make Italy famous in the world ${ }^{2}$. Dolce visited San Gregorio Armeno earlier to meet the inhabitants and talk about the need to limit the access to the inhabitants of the city

\footnotetext{
${ }^{2}$ D Repubblica, https://video.d.repubblica.it/moda/dolce-and-gabbana-a-napoli-I-alta-moda-come-non-Iavete-mai-vista/5490/5629? refresh_ce [Last access 27//2/2017]
} 
(Figure 3) to give the opportunity to the international guests who would join the event to explore Naples ${ }^{3}$.

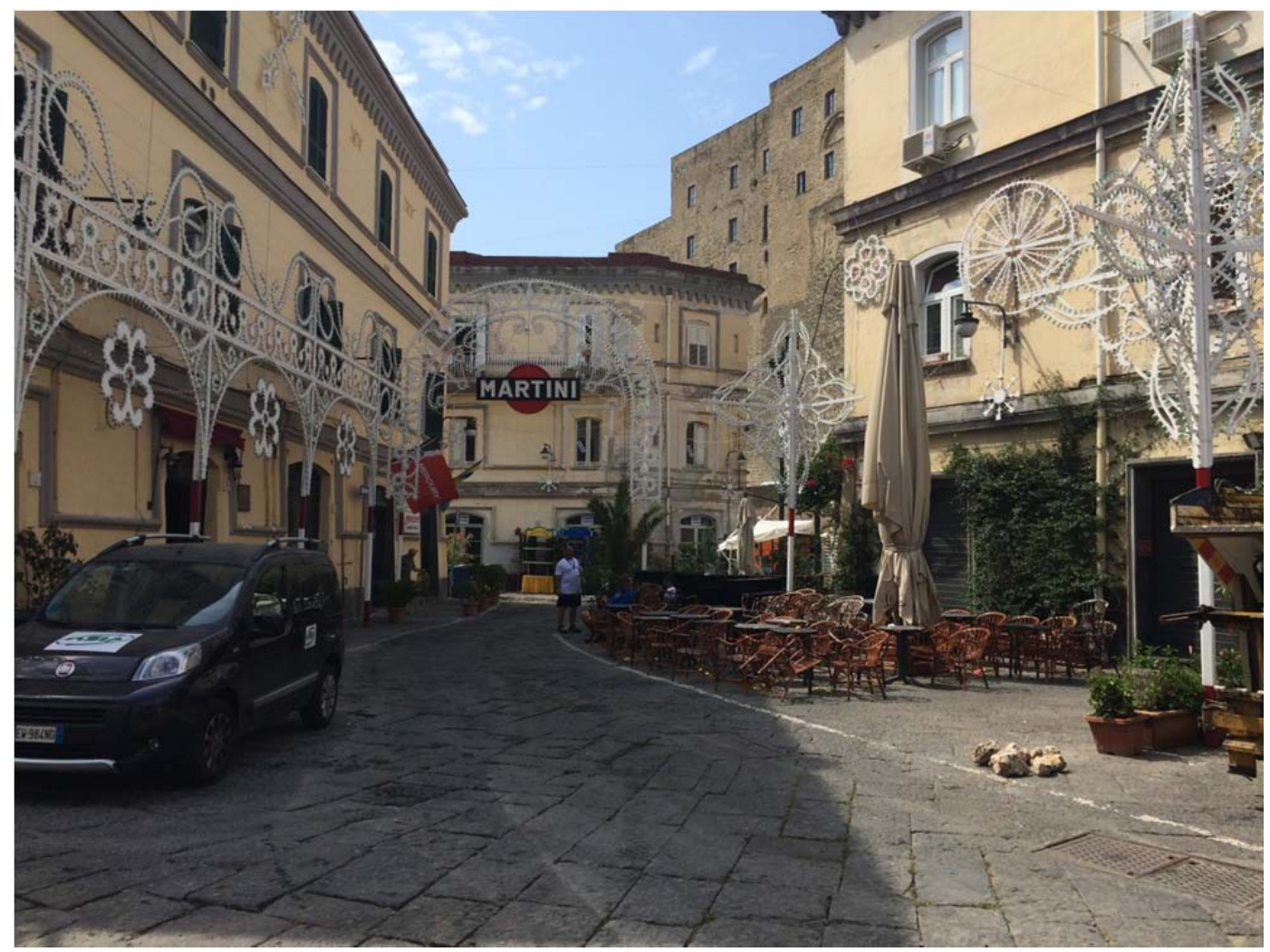

Figure 3. Borgo Marinari, one of the places chosen for the celebration of the thirties anniversary of D\&G (Source: Authors).

The creations presented in the fashion show, including 50 pieces of jewellery, 99 women's outfits and 98 men's outfits, were inspired by Dolce \& Gabbana's muse Sophia Loren and Neapolitan culture. Models wore Maradona's t-shirts, dresses with St. Gennaro's crown (Figure 4), dresses embroidered with horseshoes, red horns, and other elements, which guests could find in the shops in San Gregorio Armeno after the show ${ }^{4}$.

The major of the city, Luigi De Magistris, at the time was interviewed to discuss about the inaccessibility of the areas used for the show and presented the initiative as an important milestone to the international exposure of the city ${ }^{5}$ (Figure 5).

De Magistris highlighted how such event could bring incomes to the city, resources to restore the areas used for the event, but also job and sales opportunities in local stores that showcased their creations to international guests ${ }^{6}$. On top of that, he used the

\footnotetext{
${ }^{3} \mathrm{D}$ Repubblica, https://video.d.repubblica.it/moda/dolce-and-gabbana-a-napoli-I-alta-moda-come-non-Iavete-mai-vista/5490/5629?refresh_ce [Last access 27//2/20I7]

${ }^{4}$ I 843 Magzine, https://www. I843magazine.com/features/the-frockstar-treatment [Last access $27 / 12 / 2017]$

${ }^{5}$ YouTube, https://www.youtube.com/watch?v=LJVvPg_QGUM [Last access 27/I2/20I7]

${ }^{6}$ YouTube, https://www.youtube.com/watch?v=LJVvPg_QGUM [Last access 27/I2/20I7]
} 
term "contamination"7 to define the event, as an encapsulation of Naples, its icons. This definition was synthesized in the video of the campaign analyzed for this chapter.

Contamination also includes the encounter between the international guests, captivated by the enchantment of the city, and the inhabitants who welcomed them.
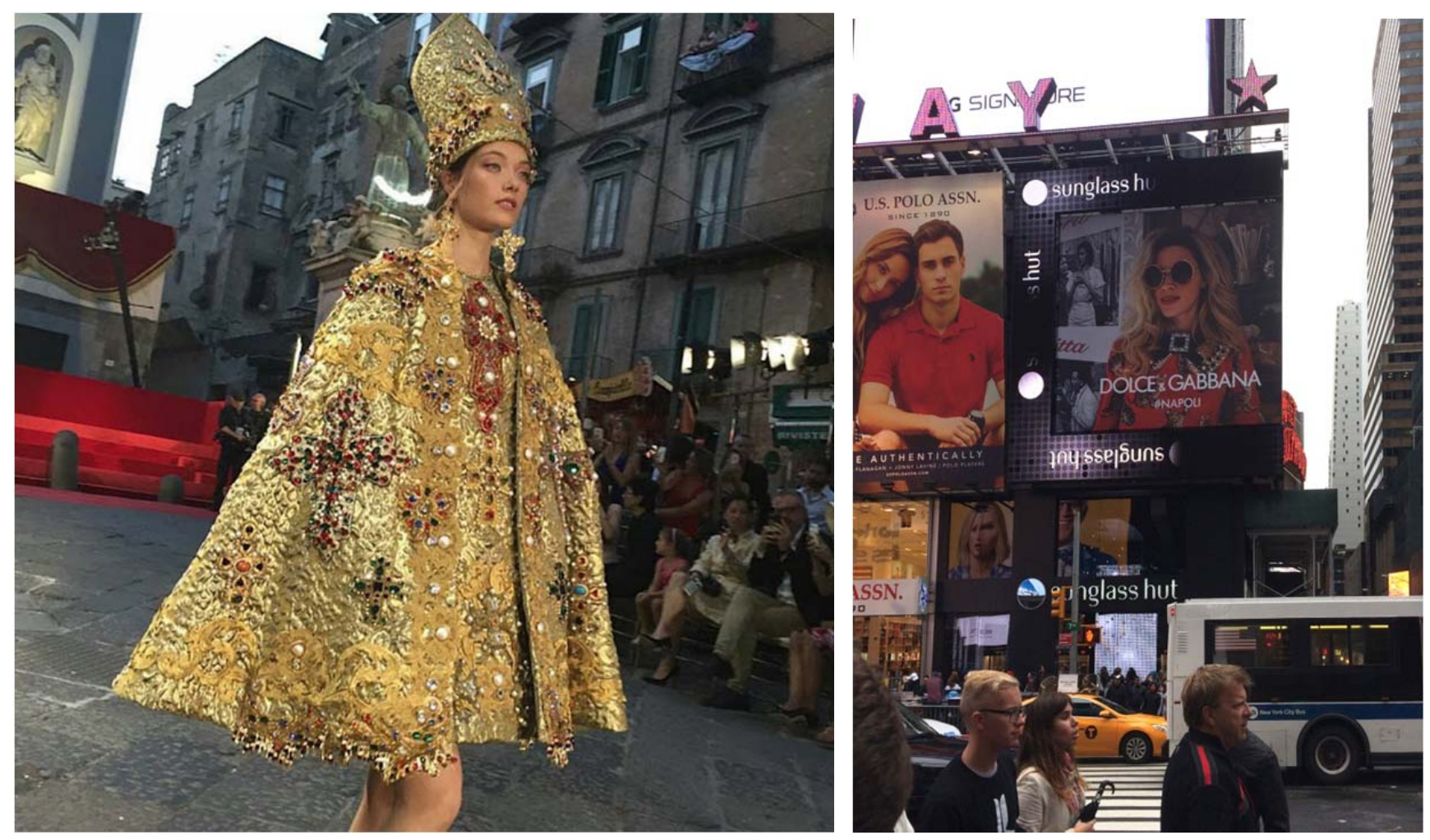

Figure 4 (left). A dress of the fashion show inspired by San Gennaro, the patron saint of the city (Source: https://www.coolchicstylefashion.com/20 / 6/07/runway-dolce-gabbana-alta-moda-fashion.html)

Figure 5 (right). Dolce \& Gabbana's advertising campaign in Times Square in New York (Source: Authors).

\section{Research methods}

The dataset used for the discussion is the video created by the brand for the occasion ( $1: 15$ mins) and retrieved from Dolce \& Gabbana's YouTube channel. ${ }^{8}$ We also included authors' participation to the event secondary data from D\&G website, media coverage of the event and the following advertising campaign in our analysis. The video has been divided into different frames and 18 scenes have been identified as representative sample of instances of mutual branding between the brand and the city based on the use of cultural representations of Italianicity. Based on the interpretation of the frames as signifiers and signifieds, the visual construction and realization of the meanings has been matched with the branding function reflecting the brand agenda behind the video. The analysis of the video created by the brand to share the media event shows the relation between selected signifiers and signifiers representing the mutual contribution between brand and city in terms of cultural identity. The interactive semantics from

\footnotetext{
${ }^{7}$ YouTube, https://www.youtube.com/watch?v=LJVvPg_QGUM [Last access 27/12/2017]

${ }^{8}$ YouTube, https://www.youtube.com/watch?v=jKy17-jVYMU [Last access 27/I2/20I7]
} 
Kress \& van Leeuwen (1996) has been deployed to understand the engagement of the viewer with the scenes, in combination with the observation of the sequence of frames drawing upon Nervino's (2017) sequential construction of social media posts.

\section{Preliminary findings}

The video Fall/Winter 2016 advertising campaign shot in the first weeks of July culminated with the Alta Moda Fashion Show held on 9 July 2016 and published on YouTube on 29 July 2016 collected over 45,000 views. The sophisticated arrangement of sounds and colours offer a 360 degree-portray of Naples. It opens with a "tarantella napuletana", a folkloristic Southern Italian dance. The use of music immediately contextualizes scenes, that construct a full narrative and tell the story of the encounter between the brand and the city impersonated by the models and the inhabitants of the city respectively.

The frames of the video, analysed as carrier of the elements of Italianicity branding the event, are unpacked in Table I in terms of visual constructions and branding functions enacted.

Table I Findings

\begin{tabular}{|c|c|c|}
\hline $\begin{array}{l}\text { Timeframe } \\
\text { (seconds) }\end{array}$ & Visual construction & Branding function \\
\hline
\end{tabular}

PART I

0:00-0:09 - Sequence of frames contextualizing the - Identification of the city and event. A summary of places and cultural contextualization characters involved are presented.

0:09

- In the background is a close-up of Bianca Balti's face.

- At her back it is possible to recognize Via San Gregorio Armeno.

- Overlapping the name of the brand 'DOLCE \& GABBANA' and the hashtag to semantically categorize the consequent branding and usergenerated content '\#NAPOLI'. The hashtag as such will gather all the content available about the city.
- Identification of the specific places within the city and celebrity endorsement.

- Bianca Balti is the protagonist of the campaign.

- The choice of the hashtag, carrying the name of the city only, will merge the D\&G campaign with the content disseminated in the social media about the city identity. In this way the one-time event will become part of the city heritage.

$0: 012-0: 25$

- Sequence of frames which portray the models and the inhabitants of the city in interaction.
- Overview of the events from different angles suggesting that the different participants and actions are occurring simultaneously in a big party. 
PART 2

\begin{tabular}{|c|c|c|}
\hline $0: 25$ & $\begin{array}{l}\text { - Shops with billboards naming the food } \\
\text { products. }\end{array}$ & $\begin{array}{l}\text { Food culture used as attention } \\
\text { grabber in the photo. }\end{array}$ \\
\hline $0: 26$ & $\begin{array}{l}\text { Male models in front of a street shop } \\
\text { in Via dei Tribunali. }\end{array}$ & $\begin{array}{l}\text { Food culture used as attention } \\
\text { grabber in the video. }\end{array}$ \\
\hline $0: 27$ & $\begin{array}{l}\text { - San Lorenzo Maggiore in via dei } \\
\text { Tribunali } \\
\text { - Female models drinking coffee }\end{array}$ & $\begin{array}{l}\text { Food culture used as attention } \\
\text { grabber in the video. }\end{array}$ \\
\hline $0: 30$ & $\begin{array}{l}\text { The encounter between models and } \\
\text { inhabitants of the city. A hug and a kiss } \\
\text { welcoming the brand as an old friend. }\end{array}$ & $\begin{array}{l}\text { Food culture used as attention } \\
\text { grabber in the video. }\end{array}$ \\
\hline $0: 42$ & $\begin{array}{l}\text { A female model walking in piazza San } \\
\text { Gaetano in Via dei Tribunali. } \\
\text { - The inhabitants are waiting for her to } \\
\text { pass as they would with a procession } \\
\text { of a saint. }\end{array}$ & $\begin{array}{l}\text { The city in this scene becomes a } \\
\text { catwalk and the inhabitants are } \\
\text { in the front row. }\end{array}$ \\
\hline $0: 51$ & $\begin{array}{l}\text { A runway of female models in the } \\
\text { streets and all female inhabitants are in } \\
\text { the front row. }\end{array}$ & $\begin{array}{l}\text { The city in this scene becomes a } \\
\text { catwalk and the inhabitants are } \\
\text { in the front row. }\end{array}$ \\
\hline $0: 52$ & $\begin{array}{l}\text { - Male models in Via dei Tribunali eating } \\
\text { pizza }\end{array}$ & $\begin{array}{l}\text { Food culture used as attention } \\
\text { grabber in the video. }\end{array}$ \\
\hline $0: 56$ & $\begin{array}{l}\text { - Female models walking in Piazzetta } \\
\text { Nilo }\end{array}$ & - City as a catwalk \\
\hline $0: 57$ & $\begin{array}{l}\text { - Male models walking in the streets } \\
\text { - Billboard of a coffee shop 'Caffe' } \\
\text { Capparelli' on the background }\end{array}$ & $\begin{array}{l}\text { Coffee is part of Italian lifestyle. } \\
\text { It brings the brand closer to the } \\
\text { inhabitants of the city. }\end{array}$ \\
\hline $0: 58$ & $\begin{array}{l}\text { Female models walking out from the } \\
\text { church of San Gregorio Armeno }\end{array}$ & $\begin{array}{l}\text { The runway is metaphorically } \\
\text { compared to a religious } \\
\text { procession in which the models } \\
\text { replace the statues. }\end{array}$ \\
\hline
\end{tabular}

PART 3

\begin{tabular}{|c|c|c|}
\hline $\mathrm{I}: 00$ & $\begin{array}{l}\text { Female models entertaining the } \\
\text { inhabitants of the city dancing } \\
\text { 'tarantella' }\end{array}$ & $\begin{array}{l}\text { - Southern Italian elements } \\
\text { characterize the campaign } \\
\text { - It is a homage of D\&G to its } \\
\text { source of inspiration }\end{array}$ \\
\hline $\mathrm{I}: 02$ & $\begin{array}{l}\text { - The models become street dancers to } \\
\text { entertain the inhabitants of the city }\end{array}$ & $\begin{array}{l}\text { - Southern Italian elements } \\
\text { characterize the campaign. It is a } \\
\text { homage of D\&G to its source of } \\
\text { inspiration. }\end{array}$ \\
\hline
\end{tabular}




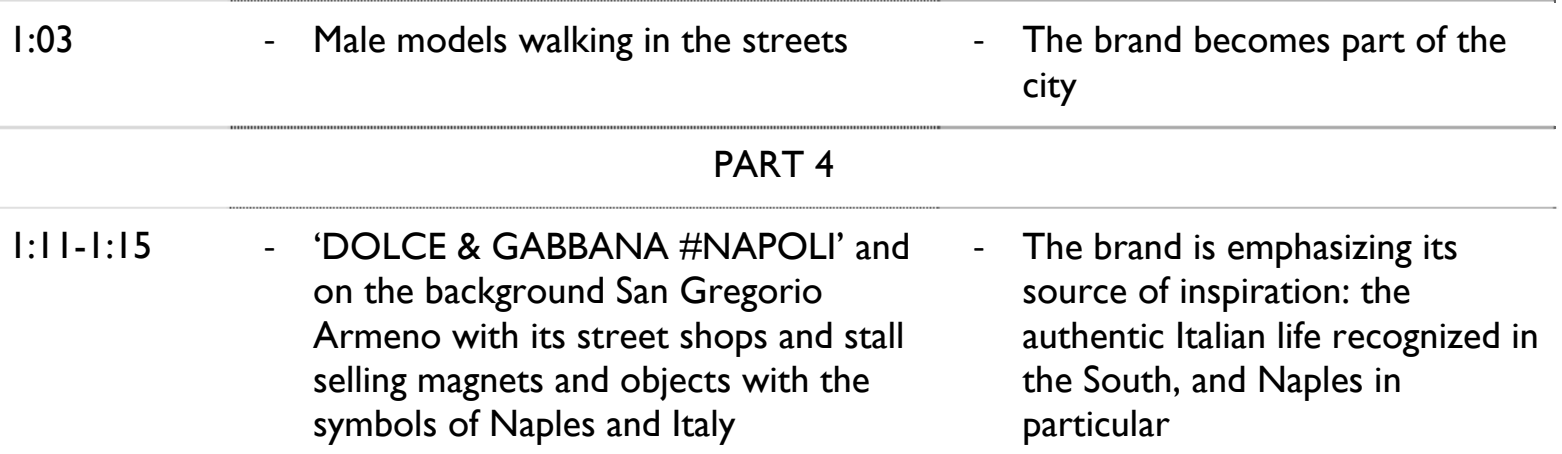

Table I shows the unfold of the story. This first part of the video shows a cultural exchange between models and inhabitants of the city. The models learn cultural rituals of life in Naples and it suggests how Dolce \& Gabbana embeds Italianicity in its concept and consequently in its products. Following the time frames, the first sequence (0:000:09) shows the Decumani chapel, whose image is presented in a position of power (Kress \& van Leeuwen, 1996) dominating the scene. These first seconds of overview of the place along with the soundtrack serve as contextualization of the story. Within this time frame, the models start walking along Via dei Tribunali (0:0I) and it is possible to recognize elements, which recall both religious and profane symbols such as the crow of saints and horseshoes embroidered into jackets. While looking at the models walking along the street the viewer's angle equals (Kress \& van Leeuwen, 1996, 2006) to the models and it creates the effect of being in the front-row of the show while watching the video. The time frame 0:02 shows Saint Biagio Church, represented in a power position, together with the San Gregorio Armeno, known as the street of cribs (0:04). The camera takes the viewer in the front row seat of the runway (low angle) where one can see the models as part of a religious procession in which Bianca Balti, the leading model of the campaign, appears as a holy icon in a position of power.

Throughout the video, facial expression of Napoli's citizens play an important role, each and every character incarnates the image of the city happiness, bitterness, anger, defeat, all strong emotions, which describe the passion of the city. Male models seem to be spectators of a catwalk dominated by women and in the sequence of gazes a dialogue is established between them.

The time frame 0:09 is a close-up of Bianca Balti with the wording "DOLCE \& GABBANA \#NAPOLI". D\&G chose the hashtag carrying the name of the city and disseminated the content via social media. Thanks to this, the one-time event will become part of the city media heritage. The time frame 0:12-0:25 recaps all the places introduced in the first 12 seconds in a sequence under the form of a prism which shows different places from different perspectives (Nervino, 2017). This first part of the video shows a cultural exchange between the models and the inhabitants of the city. The models learn cultural rituals of life in Naples and this suggests how Dolce \& Gabbana embed Italianicity in their concept and consequently in their products.

In the second part of the video, the contamination starts with an ascendant climax. Reaching the time frame 0:25 male models talk with each other in Piazza San Gaetano in Via dei Tribunali in front of a bakery 'Panificio Forno a legna'. The billboard of the bakery highlights 'mozzarella di bufala' from Aversa is available. Buffalo mozzarella is 
made by local factories in Campania (the region which Naples belongs to) and is distributed worldwide, under the regional brand. This is the first example of food ('pasta'(0:26), 'caffe"(0:27)) to characterize Italian authenticity and quality while reaching San Lorenzo in Via dei Tribunali. The time frame 0:30 portrays a shop selling traditional pastries 'sfogliatelle', signature sweets from Naples.

The different scenes show the encounter of models and inhabitants in-between food culture. This eliminates the distance between brand and city by blending the two into one Italian icon. It culminates in the time frame 0.43 when models and inhabitants hug each other and start dancing. In the time frame 0.57 coffee is used as the element to bring together models and inhabitants.

In the third part of the video, the contamination reaches the peak. The following seconds I.00-I.03 show models and inhabitants dancing 'tarantella' and it seems now that the brand has become part of the city. At 1.07 the music stops and the video continues with the sounds of the city, some wind, steps, and dogs barking.

The fourth part, D\&G and Naples are one. Time frame I.I I-I.I5 is a triumph of the brand in the street, models are smiling at each other, and have blended into the city where they walk confident to be part of it. The last time frame is a shot of San Gregorio Armeno with a booth with magnets on sales which recap the symbols of Naples' tradition, and again the wordings "DOLCE \& GABBANA \#NAPOLI".

Overall, the video tells the story of the encounter of the brand incarnated by the models and the city impersonated by the inhabitants. Throughout the video the models acquire the cultural traits of the city mainly through food and mingling with the inhabitants through dancing and singing. At the end of the video, the models seems to be more familiar with the city and "contaminate" it, as described by De Magistris. The models shift from being the protagonists of the catwalk to being a part of the city. There is no longer a difference between stage and audience, by the end of the show, all has merged together.

The presence of people of the city disrupts a key feature of high-end brands' advertising campaigns. Usually, brands define controlled settings and situations in order to preserve their brand aura and positioning; however, in this case the presence of city's inhabitants to animate the scene create a kind of uncontrolled setting. In fact, media coverage has not missed the chance to highlight how, while featuring the inhabitants of the city, D\&G also featured other popular brands among them such as Armani, Givenchy and Louis Vuitton accessories, which happen to be worn'. D\&G accepted the cons of an uncontrolled settings on exchange for the benefit of being associated with the iconic city of Naples, and for the purpose of engaging the community to show the city in its authenticity (Figure 6).

\footnotetext{
9 Vanity Fair, https://www.vanityfair.it/fashion/borse//6/06/23/dolce-gabbana-pubblicita-armani-jeans [Last access $27 / 12 / 2017]$
} 


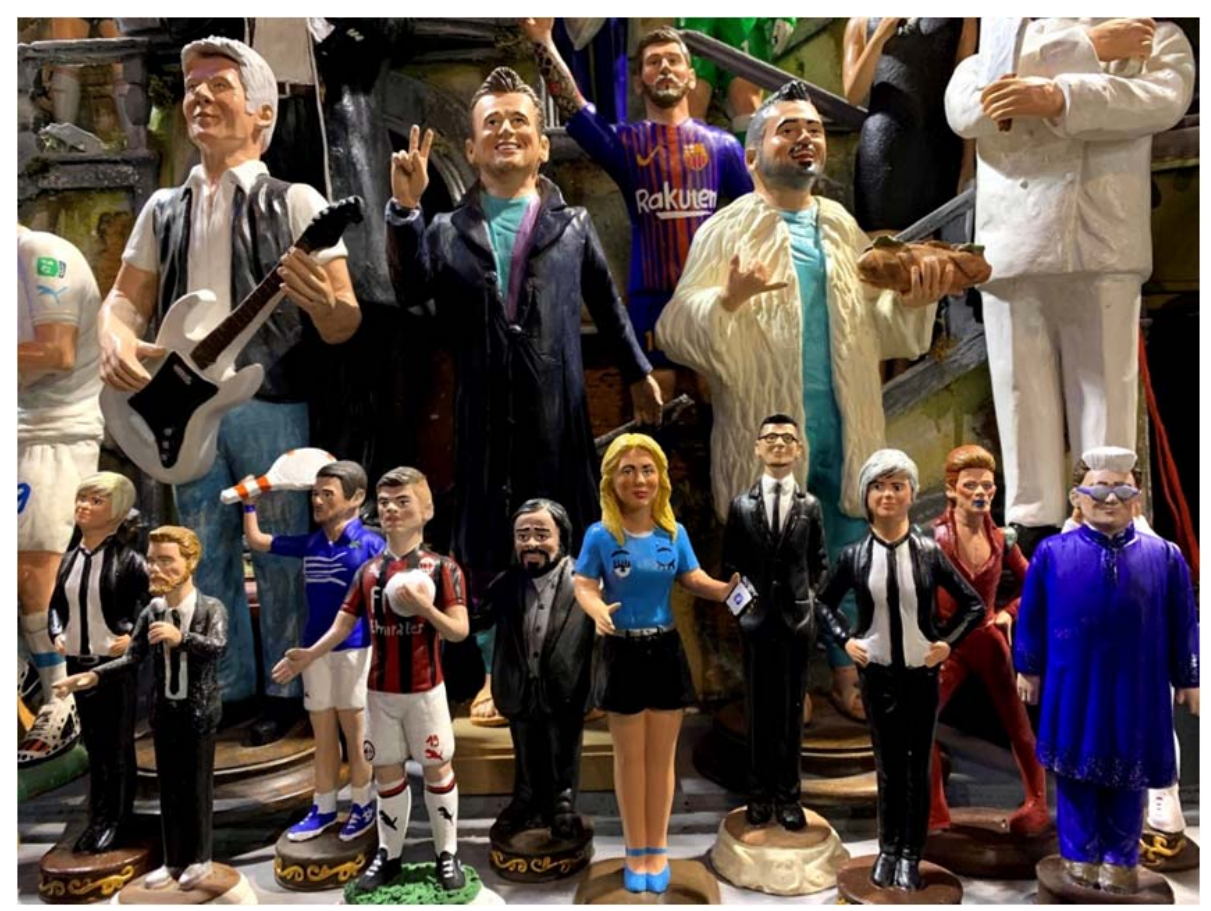

Figure 6. D\&G in the iconic world of the caricatures of celebrities like politicians, singers and TV personalities exhibited in via San Gregorio Armeno. The street is crowded, especially during the Christmas period, with hundreds of artisan workshops with colorful displays of Nativity scenes (Source: Authors).

\section{Discussion}

The celebration of the thirtieth anniversary of D\&G revealed how distinguished urban spaces, and especially the historical city, are a perfect stage for fashion brands and advertising campaigns. D\&G's event was focused on highlighting a specific narrative; the vibrancy and the most distinctive aspects of Neapolitan people to reinforce stereotypes such as theatrical aspects and their adherence to the Southern Italian popular culture. Obviously, the question is whether this image is the most suitable to relaunch the future of a city which is unable to attract new businesses and therefore create alternative jobs opportunities.

Unlike some of Italy's major tourist cities such as Venice, Florence, and partly Rome, Naples is not yet affected by a musealisation process (Figure 7), its downtown is fully inhabited by multiple stories and tradition of its citizens. The 'Neapolitan renaissance' initiated in the first decade of $\mathbf{2 0 0 0}$ with Antonio Bassolino then mayor. He started a process which slowly changed the negative reputation of the city for being chaotic and dangerous. In 2018, according to the Italian Institute of statistics, Naples was one of the most visited Italian cities and the trend in 2019 was even better. Furthermore, new redevelopment projects such as the transformation and implementation of the city's subway system has created new opportunities to regenerate public spaces in different districts as well as decongest the city's notorious traffic. 


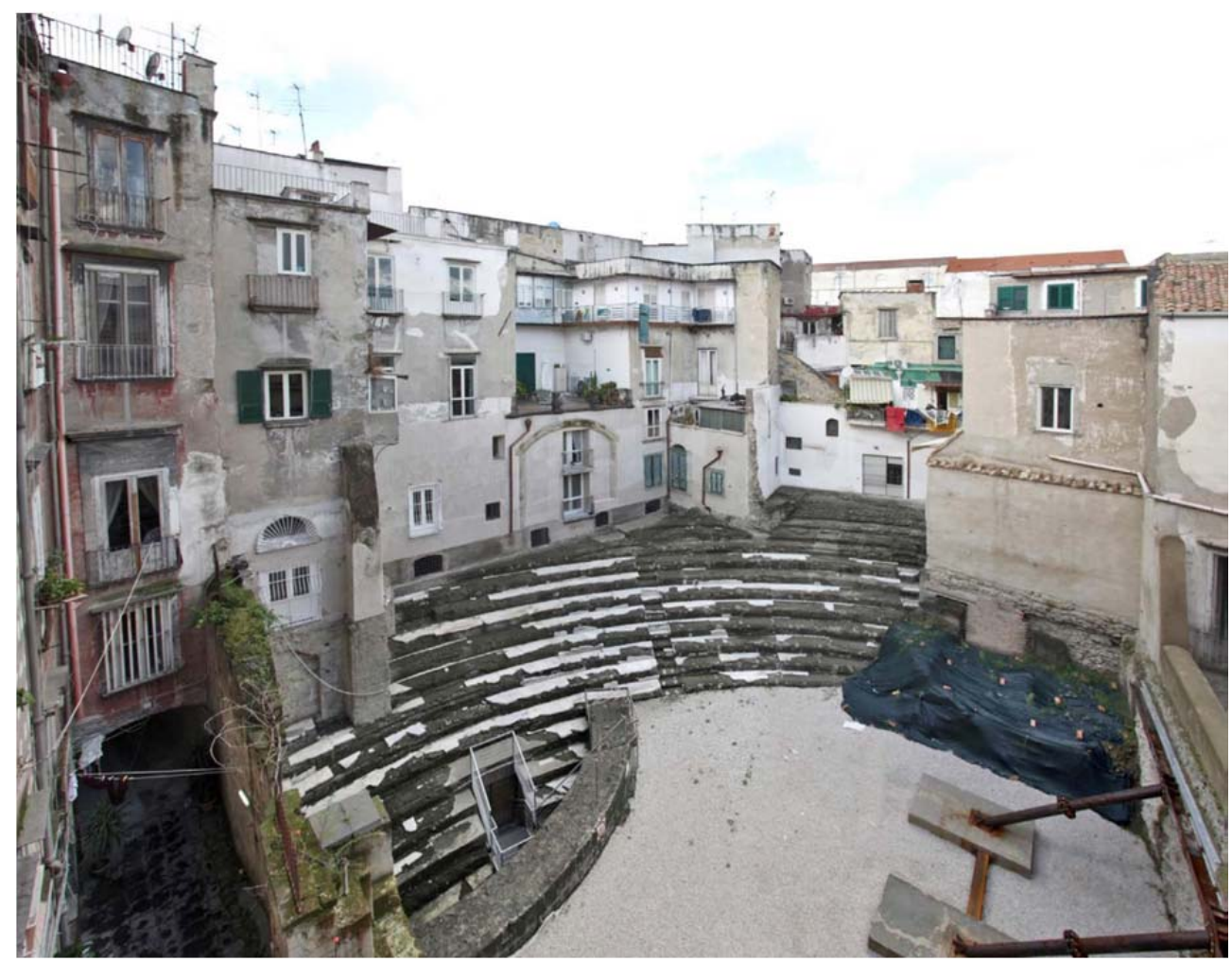

Figure 7. The 'inhabited' ancient Roman theater of Neapolis situated in the core of the downtown (Source: Authors).

In this regard, it is not a coincidence that D\&G's event rode the wave of the cultural regeneration of Naples. The event became an instance of exploration of alternative ways to promote a specific image of the city. The analysis showed that the event generated a positive impact on the regeneration of urban spaces as well as promoting cities as cultural and fashion symbols. The thirties' anniversary of D\&G, the recurrent use of Southern Italian elements in their creations, and the Fall-Winter 2017 advertising campaign threw Naples on the catwalks, and shopping windows of the whole world and projected the city in the fashion system.

However, despite this global exposure, which enhanced the city's brand internationally, some criticism was made on the fact that the fashion show constructed only a stereotypical representation of Naples. Furthermore, another issue was related to the exclusivity of the event. Popular tourist destinations of the city were closed to the general public for almost 60 hours creating problems to residents and tourists (Figure 8).

As described, the free usage of different areas of the city granted by the municipality of Naples was compensated by D\&G with donations used for different purposes. As Anna Paola Merone noted in a Corriere del Mezzogiorno article published on 05 July 2016, almost 40 thousand euros were used for security and cleaning, a figure to which must be added a donation of 50 thousand euros for the Decumani area and I 5 thousand euros for the lease of Castel dell'Ovo as well as other private funds to rehabilitate different buildings and monuments. 


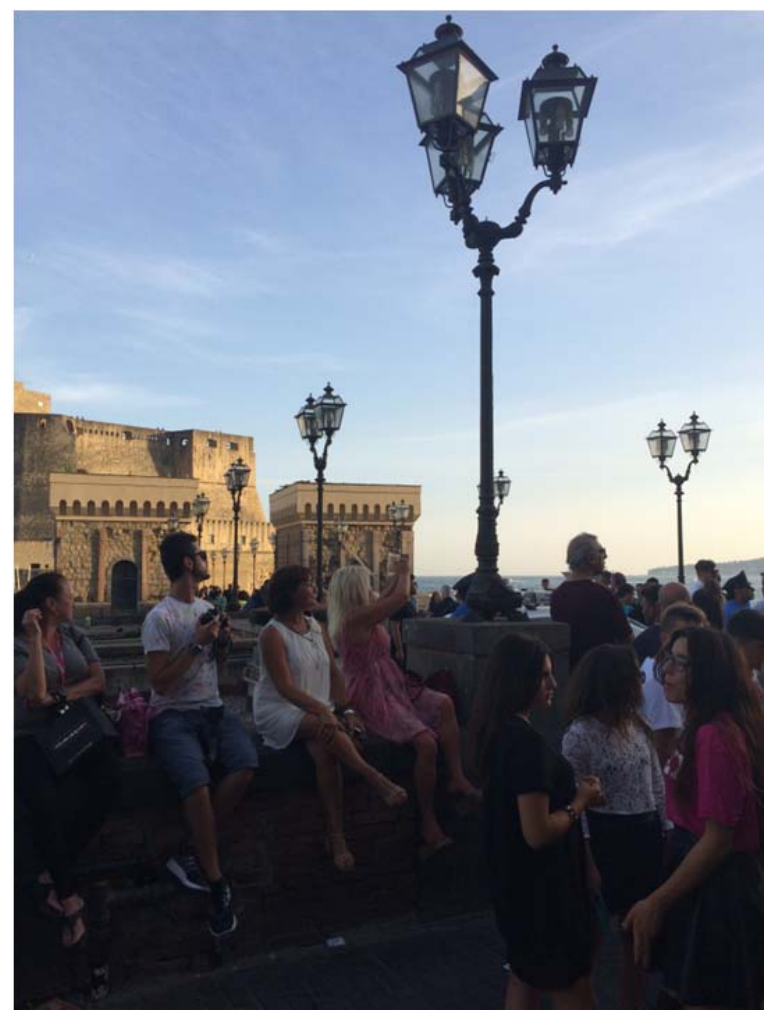

Figure 8. A small crowd gathered outside the limited access area used for the show. (Source: Authors)

This event opened a debate regarding the use of private investment to redevelop the cultural heritage and historic districts. Nowadays, it is hard to supply the lack of financial resources that many cities face, and it may be necessary to consider the adoption of public-private partnerships (PPP) to enhance the condition of the urban environment. These funding mechanisms often require continuous incentives which can encourage urban investment through tax relief or through property tax specifically earmarked for the development.

The city of New York for example, established in the early 1980s the policy of the Business Improvement District (BID). This policy allows organizations formed by private property owners and businesses to pay a special tax to cover the expense of providing their district with services beyond what the local municipality offers in their area. This type of policy was first introduced in Europe in the 2000s, in countries such as the Netherlands (Bedrijven investeringszones), Germany (Neighbourhood Improvement Districts), in Great Britain, Serbia and Albania. In Italy, these kinds of PPP are not common, however, in recent years they are becoming more popular. In Milan for example the municipality has started several pilot projects importing the BID concept from New York.

The BID model creates a reliable funding source to supplement services and programs to an area of the city. These services typically include public safety, marketing of a neighbourhood brand and planning efforts. The popularity of the BID model grew because they offer the ability to respond more quickly than the public sector to the changing needs of the business community. Moreover, the private sector prefers 
dedicated funding sources and control over planning and programming offered by BIDs (Stokes, 2006).

In Naples the adoption of BIDs could facilitate the creation of alternative tourist destinations. In the city there are strong manufacturing traditions with neighbourhoods that were once specialized for the artisanal production of jewellery, textiles, clothing and leather goods. However, the rising popularity of Naples as a rediscovered travel destination is increasing the massive opening of small businesses related to the food industry. Undoubtedly, these food-related activities are crucial for the economy of region and the city, but a more long-term vision for the future of the city would be necessary to consolidate this favourable moment.

The BIDs could successfully leverage private funding and catalysing efforts to reinstate the role of Naples as a creative and Mediterranean cultural hub of south Italy. For instance, the institutionalization of a city's creative districts (CCD) section within the municipality could help to elevate, differentiate and distribute the tourist flows in different areas as well as facilitate the adoption of alternative branding strategies. Potentially, the CCDs in partnership with the private sector will focus on the reactivation of the jeweller's district (i.e. Borgo degli Orefici), on the reorganization of the food areas, but also on the creation of a new art and design district as well as several specialized manufacturing zones related to a brand-new fashion district.

\section{Conclusion}

As argued, the synergic strategies between public and private, if well regulated, could facilitate the management and the maintenance of strategic areas of the city, reinforce the image and branding identity as well as open alternative ways to attract new businesses, commercial investors, consumers and tourists.

It must be acknowledged that the dichotomy between private and public space has always been a topic of central importance for the understanding of urbanity and the development of cities. In this regard, as the role of the private sector has increased, the proliferation of different types of urban, hybrid spaces has followed (Nissen 2008). According to Cho et al. $(2016,5)$ the traditional distinction between private and public realm "seems to be somewhat problematic and insufficient for understanding the contemporary contexts of emerging new hybrid urbanities and modes of publicness." The study creates room for intersection of cultural, branding and urban studies to further theoretical contribution to the development of frameworks to analyse cities as texts carrying an evolving narrative and its semiotization across media. Furthermore, the study enriches the literature about branding and $\mathrm{CoO}$ with the urban perspective, often disregarded by marketing scholars. Additionally, this article contributes to the existing literature and re-opens the debate of public space use with a set of new tools to generate value for the city and its inhabitants thanks to partnerships with private entities. A value, which does not necessarily entail monetary transactions but agreements on mutual benefits to produce and reproduce a long-term positive impact. Further research will look at the resemiotization of these types of events considering different media together with similar instances, given the conspicuous use of cities as stage for fashion brand's campaigns. A larger corpus of data with a wide range of case studies will be analysed to identify patterns and trends of this phenomenon. In this regard, the study of several events and cities, will draw attention to the impact that 
branding can have on urban regeneration as well as providing scholars with a framework for future applications and policy makers for more proof of concepts to support the practice.

\section{References}

Aiello G., Donvito R., Grazzini L., \& Petrucci E. (2016). The relationship between the territory and fashion events: The case of Florence and Pitti Immagine fashion fairs. Journal of Global Fashion Marketing, 7, I50-165.

Avraham, E. (2000). Cities and Their News Media Images. Cities 17(5), 363-370.

Banerjee, T. (200I). The future of public space: Beyond invented street and reinvented places. Journal of the American Planning Association 67(I), 9-24.

Barthes, R. (1987). Image-music-text. (S. Heath, Trans.) Fontana: London.

Belfanti, G. (2015a). History as intangible asset for the Italian fashion business. Journal of Historical Research in Marketing, 7(I), 74-90.

Belfanti, G. (20I5b). Renaissance and Made in Italy: marketing Italian fashion through history. Journal of Modern Italian Studies, 20(I), 53-66.

Bertoli, G., Busacca, B., Ostillio, M. C., \& Di Vito, S. (2016). Corporate museums and brand authenticity: Explorative research of the Gucci Museo. Journal of Global Fashion Marketing, 7, $181-195$.

Bucci, A., Codeluppi, V. \& Ferraresi M. (20I I). II Made in Italy. Natura, settori e problemi. Roma: Carocci Editore.

Burden, A. (20I4). Amanda Burden: How public spaces make cities work [Video File]. Retrieved from: https://www.ted.com/talks/amanda_burden_how_public_spaces_make_cities_work [Last access $27 / / 2 / 2019]$

Calvino, I. (2006). Invisible Cities (W. Weaver Trans.). Orlando, FL: Harcourt.

Calvino, I. (1983). Calvino on "Invisible Cities". Columbia: A Journal of Literature and Art, 8(Spring/Summer), 37-42.

Capone F., \& Lazzeretti, L. (2016). Fashion and city branding. An analysis of the perception of Florence as a fashion city. Journal of Global Fashion Marketing, 7, 166-I80.

Carmona, M. (2015). Re-theorising contemporary public space: a new narrative and a new normative. Journal of Urbanism: International Research on Placemaking and Urban Sustainability, 8(4), 373-405.

Caroli, M. G. (2014). Il marketing per la gestione competitiva del territorio. Modelli e strategie per attrarre (e far rimanere) nel territorio persone, imprese e grandi investimenti. Milano: Franco Angeli.

Cervellati P.L. (2000). L'arte di curare la città. Milano: II Mulino.

Cho, I.S., Heng, C-K. \& Trivic, Z. (2016). Re-framing urban space: urban design for emerging hybrid and high-density conditions. New York, NY: Routledge.

Cleave, E., Arku, G., Sadler, R. \& Gilliland, J. (2016). The role of place branding in local and regional economic development: bridging the gap between policy and practicality. Regional Studies, Regional Science, 3 (I), 207-228.

Corbellini, E., \& Saviolo, S. (2007). L'esperienza del lusso. Mondi, mercati, marchi. Milano: ETAS, RCS Libri S.p.A.

Croce, B. (1927). Il paradiso abitato da diavoli. Reprint in Uomini e cose della vecchia italia, Bari: Laterza, series I, 3rd ed. (1956) 68-86. 
Cuthbert, A., \& McKinnell, K. (200I). Public domain, private interest - Social space in Hong Kong. In Miao, P. (Ed.) Public Places of Asia Pacific Countries: Current Issues and Strategies (pp.190-2II). The Netherlands: Kluwer Academic Publishers

D Repubblica, https://video.d.repubblica.it/moda/dolce-and-gabbana-a-napoli-l-alta-moda-comenon-l-avete-mai-vista/5490/5629?refresh_ce [Last access 27/I2/2019]

Dastgerdi, S. A. \& De Luca, G. (2019). Strengthening the city's reputation in the age of cities: an insight in the city branding theory. City Territ Archit, 6(2). Doi: https://doi.org/10.1186/s40410-019-0101-4.

De Carlo, M., Canali, S., Pritchard, A., \& Morgan, N. (2009). Moving Milan towards Expo 2015: Designing Culture into a City Brand. Journal of Place Management and Development 2(I), 28-22.

De Solà Morales, M. (1992). Un nuevo reto: Urbanizar lo Privado. Espacios públicos y espacios colectivos. La Vanguardia, Sección de Cultura y Arte, Barcelona.

Dinnie, K. (20II) (ed.) City Branding. Theory and Cases. Basingstoke, New York: Palgrave Macmillan.

Dion, D., \& Mazzalovo, G. (2016). Reviving sleeping beauty brands by rearticulating brand heritage. Journal of Business Research, 69(12), 5894-5900.

Dolce \& Gabbana Facebook page, https://www.facebook.com/DolceGabbana// [Last access $27 / 12 / 2019]$

Dolce \& Gabbana website, http://www.dolcegabbana.com/corporate/en/group/profile.html [Last access $27 / / 2 / 2019]$

Donskis, L. (2009). Troubled identity and the modern world. New York and Basingstoke: Palgrave Macmillan.

Fabris, G., \& Minestroni, L. (2004). Valore e valori della marca. Come gestire una marca di successo. Milano: FrancoAngeli.

Graham, S. (200I). The spectre of the splintering metropolis. Cities I8 (6), 365-368.

Hall, S. (1995). New cultures for old. In Massey, D. \& Jess, P. (Eds.) A place in the world (pp. 175214). Milton Keynes: Open University Press.

Hall, S. (2006). Encoding/decoding. In Durham, M. \& Kellner, D. (Eds.) Media cultural studies: keyworks. Malden: Blackwell Publishing, 163-I73.

Hajer, M. A. \& Reijndorp, A. (200I). In Search of New Public Domain: Analysis and Strategy, Rotterdam: NAi Publishers.

Herstein, R., \& Berger, R. (2013). Much More Than Sports: Sports Events as Stimuli for City Rebranding. Journal of Business Strategy 34(2), 38-44.

Hjelmslev, L. (1963). Prolegomena to a theory of language. (F. Whitfield, Trans.). Madison: University of Wisconsin Press.

Hospers, GJ. (2009). Lynch, Urry and City Marketing: Taking Advantage of the City as a Built and Graphic Image. Place Branding and Public Diplomacy 5(3), 226-233.

Jansson, J. \& Power, D. (2010) Fashioning a global city: global city brand channels in the fashion and design industries. Regional Studies, 44(7), 889-904.

Jaworski, A. \& Thurlow, C. (20I0). Introducing semiotic landscapes. In Jaworski, A. \& Thurlow, C. (Eds.) Semiotic landscapes: language, image, space (pp. I-40). London: Continuum.

Kapferer, J. N. (2008). The new strategic brand management. Creating and sustaining brand equity long term. (4th ed.). London and Philadelphia: Kogan Page Limited.

Kavaratzis, M. (2004). From city marketing to city branding: Towards a theoretical framework for developing city brands, Journal of Place Branding, I(I), 58 - 73.

Karimzadeh, A., Khosravi, A., \& Dastgerdi, H.R.R. (2013). City and citizen as a text and its author: a semiotic reading. Planum. The Journal of Urbanism. Vol. 2, n. 27. NUL - New Urban Languages Conference Proceedings.

Kim, S., Shimuzi, A., \& Donvito, R. (2016). Italian fashion case study. Journal of Global Fashion Marketing, 7(3), I47-I49. 
Koolhaas, R. (2000). Rem Koolhaas with Jennifer Sigler. Interview edited by Jennifer Sigler appeared in Index Magazine and Index Worldwide. Retrieved from: http://www.indexmagazine.com/interviews/rem koolhaas.shtml [Last access 27/I2/2019]

Kowalik, I. (20I2). Influence of Trade Fairs on a Host City Brand. Viesoji Politika ir Administravimas II (4), 629-640.

Kress, G., \& van Leeuwen, T. (1996). Reading images: the grammar of visual design. London: Routledge.

Leinberger, C. B. \& Berens, G. (1997). Executive Summary: Creating better urban parks and open spaces. In Mehta, V. (Ed.) Public space: critical concept in built environment (pp. 262278). London and New York: Routledge.

Leitch, L. (October/November, 2016). The frock-star treatment. I 843 Magazine, https://www. 1843magazine.com/features/the-frockstar-treatment [Last access $27 / / 2 / 2019]$

Lau F., Leung, A. (2005). Design and City Branding - From School to City. Place Branding and Public Diplomacy I(3), 265-272.

Liu, Y., \& Chong, C. (2007). The Effects of Festivals and Special Events on City Image Design. Frontiers of Architecture and Civil Engineering in China I (2), 255-259.

Lucarelli, A., \& Berg, P. O. (20I I). City branding: A state-of-the-art review of the research domain. Journal of Place Management and Development, 4 (I), 9-27.

Mehta, V. (2015). Public space: critical concept in built environment. London and New York: Routledge.

Muratovski, G. (20I2). The Role of Architecture and Integrated Design in City Branding. Place Branding and Public Diplomacy 8(3), 195-207.

Nervino, E. (20I7). Social media is the new black: a social semiotic analysis of luxury branding discourse. PhD thesis submitted to The Hong Kong Polytechnic University, Hong Kong.

Nickerson, N.P., \& Mosey, N.R. (1999) Branding a state from features to positioning: Making it simple? Journal of Vacation Marketing, 5(3), 2I7-226.

Nissen, S. (2008). Urban Transformation from Public and Private Space to Spaces of Hybrid Character. Sociologický časopis. Czech Sociological Review, 44 (6), I I 29-I I 49.

Okonkwo, U. (2007). Luxury fashion branding: trends, tactics, techniques. Basingstoke, New York: Palgrave Macmillan.

Oldenburg, R. (2009). Celebrating the Third Place: Inspiring Stories About the Great Good Places at the Heart of Our Communities. Boston, MA: De Capo Press.

Project for Public Space (PPS) (2000). How to turn a place around: A handbook for creating successful public spaces. New York, NY: Project for Public Spaces.

Reem, A., Ayedrous, A., \& Hashim, B. (2012). Branding the Brand New City: Abu Dhabi, Travelers Welcome. Place Branding and Public Diplomacy 8(I), 72-82.

Richards, G., \& Wilson, J. (2004). The Impact of Cultural Events on City Image: Rotterdam, Cultural Capital of Europe 200I. Urban Studies 4I(I0), I93I-195I.

Robbie, B.H.G. \& Yeoh, B.S.A. (Eds.) (2003). Theorizing the Southeast Asian City as Text. Urban landscapes, cultural documents, and interpretative experiences. Singapore: World Scientific Publishing.

Rocca, F. (26 June 2016). Non notate nulla di strano? Vanity Fair, https://www.vanityfair.it/fashion/borse//6/06/23/dolce-gabbana-pubblicita-armani-jeans [Last access $27 / / 2 / 2019$ ]

Rossi, A. (1982) The architecture of the city. Cambridge, Mass: Opposition Books/MIT press.

Rossini, F. (20l4) Nuevos espacios colectivos de la ciudad vertical contemporánea: el caso de Hong Kong. PhD thesis, Universitat Politècnica de Catalunya, Barcelona.

Rossini, F., Roca, E., \& Harris, S. (2018). The Notion of Ground: A Definition of Urban Permeability in Hong Kong and Barcelona. ACE Journal: Architecture, City and Environment. I3(38), 2 II-234. doi: 10.582 I/ace. I3.38.5432 
Saussure, F. (1974). General course in linguistics. New York: Philosophical Library.

Scollon, R. \& Scollon, S.W. (2003). Discourses in place. Languages in the material world. London and New York: Routledge.

Sennet R. (1977). The fall of public man. Cambridge: Cambridge University Press

Sevcik, T. (20I I). Strategic Urban Narratives: Beyond Conventional City Branding, Development. Special Issue: Sustainable Cities 54(3), 343-344.

Smith, A. (2005). Reimaging the City: The Value of Sport Initiatives. Annals of Tourism Research $32(1), 217-236$.

Stokes, R.J. (2006) Business Improvement Districts and Inner City Revitalization: The Case of Philadelphia's Frankford Special Services District. Intl Journal of Public Administration, 29, 173-186.

Waitt G. (1999). Playing Games with Sydney: Marketing Sydney for the 2000 Olympics. Urban Studies 36(7), 1055-1077.

Westerbeek, HM., Turner, P., \& Ingerson, L. (2002). Key Success Factors in Bidding for Hallmark Sporting Events. International Marketing Review 19(3), 303-322.

Xue, K., Chen, X., \& Yu, M. (20I2). Can the World Expo change a city's image through foreign media reports? Public Relations Review 38(5), 746-754.

YouTube, https://www.youtube.com/watch?v=jKyl7-jVYMU [Last access 27//2/2019]

YouTube, https://www.youtube.com/watch?v=LJVvPg_QGUM [Last access 27/12/2019]

Zhang, L, \& Zhao, S.X. (2009). City Branding and the Olympic Effect: A Case Study of Beijing. Cities 26(5), 245-254. 